NBER WORKING PAPER SERIES

THE NEW YORK STOCK MARKET IN

THE 1920s AND 1930s: DID STOCK

PRICES MOVE TOGETHER TOO MUCH?

Peter Rappoport

Eugene N. White

Working Paper No. 4627

NATIONAL BUREAU OF ECONOMIC RESEARCH 1050 Massachusetts Avenue

Cambridge, MA 02138

January 1994

This paper is part of NBER's research program in the Development of the American

Economy. Any opinions expressed are those of the authors and not those of the National Bureau of Economic Research. 


\title{
THE NEW YORK STOCK MARKET IN \\ THE 1920s AND 1930s: DID STOCK \\ PRICES MOVE TOGETHER TOO MUCH?
}

\begin{abstract}
In this paper, we re-examine the stock market of the 1920 s and 1930s for evidence of a bubble, a "fad" or "herding" behavior by studying individual stock returns. One story often advanced for the boom of 1928 and 1929 is that it was driven by the entry into the market of largely uninformed investors, who followed the fortunes of and invested in "favorite" stocks. The recent theoretical literature on how "noise traders" perturb financial markets is consistent with this description. The result of this behavior would be a tendency for the favorite stocks' prices to move together more than would be predicted by their shared fundamentals. Our results suggest that there was excess comovement in returns even before the boom began, but comovement increased significantly during the boom and was a signal characteristic of the tumultuous market of the early 1930s. These results are thus consistent with the possibility that a fad or crowd psychology played a role in the rise of the market, its crash and subsequent volatility.
\end{abstract}

Eugene N. White Department of Economics Rutgers University New Brunswick, NJ 08903-5055 and NBER
Peter Rappoport

c/o Eugene N. Wi.ite Department of Economics

Rutgers University

New Brunswick, NJ 08903-5055 
Financial economists have invested an enormous amount of time and effort in testing whether the efficient markets hypothesis holds for the stock warket. When tests for efficiency have failed, the results have been explained either as deficiencies in the tests or as evidence for the bubbles, manias and lads of historical accounts, depending on the convictions of the researchers. Yet, despite this extensive testing of the markets, there has been relatively little effort to examine in detail the specific episodes that historians have identified as departures from fundamentals.

In this paper, we re-examine the stock market of the $1920 \mathrm{~s}$ and 1930 s for evidence of a bubble by studying individual stock returns. Most studies examining bubbles, "fads," or "herding" behavior have focused on stock market indlcas, but there is no reason why such departures from an efflcient market should be spread evenly across the market. One story often advanced for the boom of 1928 and 1929 is that it was driven in part by the entry into the market of largely uninformed investors, who followed the fortunes of and invested in a relatively narrow group of certain "favorite" stocks. The result of this behavior would be a tendency for the favorite stocke' prices to move together more than would be predicted by their fundamentals. In view of this, a symptom of the type of mispricing belleved to have occurred in the boom and crash of 1928 to 1929, would be evidence on the tendency of individual stock prices or returns to move in sympathy for reasons that cannot be accounted for by shared fundamentals. Our results, which are based on Pindyck and Rotemberg's (1990, 1992) approach, suggest that there was excess comovement in returns even before the boom 
began, but comovement increased significantly during the boom and was a signal characteristic of the tumultuous market of the early $1930 s$.

\section{The New Crowd in the Market}

Most historians and some economists treat the bull market of the 1920 s as an episode when crowd psychology overwhelmed the fundamentals that should have driven stock prices. The chief characteristic of these accounts is that it became fashionable to invest in the stock market--a fad--and a new generation of unsophisticated investors entered the market eager to make their fortunes. Allen (1931) and Galbraith (1954) recount how this enthusiasm, perhaps led by some big speculators, started with two stocks in early 1928.

Beginning with General Motors and RCA, the market started to rise with enthusiasm spreading to a larger number of stocks. The increase in prices was not uniform, and the larger firms seemed to be more favored. Both the Dow Jones index, an index of selected large firms, and the Board of Governors of the Federal Reserve's index, a value weighted index show the market rising, with an occasional brief retreat, to a peak in september 1929. However, Fisher's (1966) equally weighted index, which reveals the fate of smaller companies, grew much more slowly and reached its peak in February 1929. Furthermore, not all large firm's stock prospered, although certain groups, like banks and utilities, boomed. What 
cannot be discerned from this record is whether the enormous rise in the price of banks' and utilities' stocks, for example, may be attributable to some significant improvement in the fundamentals for these industries or an infectious enthusiasm that spread through certain parts of the market.

Allen's contemporary history of the period suggests that the market was driven by an optimism based more on rumor than dividends and earnings:

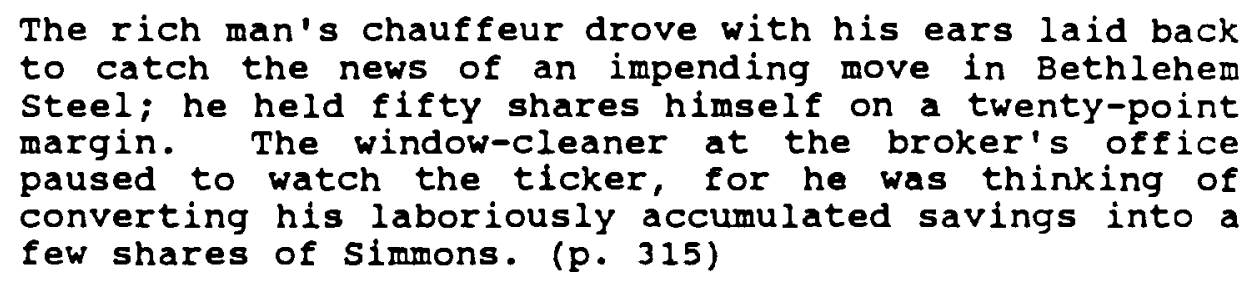

While Allen may have highlighted some working class investors for effect, the stock market does appear to have been invaded by a new class of small investors who had graduated from government securities during world war I to bonds and then stocks (White, 1984). Among the most easily identifiable new entrants to the market were women investors (Galbraith, p. 76). These developments were reflected and, in turn, stimulated by popular articles, such as "Everybody ought to Be Rich" in the August 1929 Ladies Home Journal. Surveying the psychological literature, Shiller (1984) suggested that such a surge in new investors is largely driven by group pressure. Individuals are strongly influenced by the actions of their friends and acquaintances, and thus a "fad" diffuses through a society like an epidemic.

catering to the public's new found interest in securities were 
investment trusts or mutual funds, which enabled the smaller investor to indirectly buy a portfolio selected by the fund. In 1926, there were 160 such funds. The following year 140 were formed, in 1928186 were created and in 1929265 were established (Galbraith, pp. 53-54). Investigating the behavior of the closed end mutual funds, De Long and Shleifer (1991) discovered an anomaly. When the price of a mutual fund is compared to the market prices of its constituent securities in the post world war II period, it is most common to observe a discount. However, in the period of the 1920 s bull market there was a very large premium-about 45 percent in July 1929. Given that it was feasible to replicate the composition of any fund, De Long and shleifer concluded that the premium was one sign of excessive investor optimism.

The general picture drawn by these historians and economists is of a market where the influence of the smart, well-informed investor had been substantially reduced while the activities of the more naive newcomers had grown. Recently, De Long, Shleifer, Summers, and waldman (1990) have presented a theoretical model where "noise traders," investors who base their decisions not on market fundamentals of earnings and dividends but irrelevant information, can move stock prices away from their fundamental values even in the presence of arbitrage by "smart money." The intuition behind their model is that the unpredictable behavior of noise traders makes arbitrage risky. If arbitragers had infinite horizons, arbitrage would be riskless because they could wait out 
the noise traders; but as their time horizons are finite, they cannot risklessly drive the market back to its fundamental values. The arrival of a new generation of excessively optimistic traders thus can push the market above its fundamentals and allow them to earn a higher yield as they willingly accept a disproportionate share of the risk. In line with the psychological studies, De Long et. al. have noise traders entering the market in emulation of previous generations of traders. This model thus appears to shed some light on a number of financial anomalies, including the mean reversion in stock returns, the equity premium puzzle, the pricing of mutual funds and the excess volatility of assets.

\section{Testing for Crowd Behavior}

This historical and theoretical literature suggests that stock prices may depart from their fundamental values. The tests devised by Shiller (1981) and Le Roy and Porter (1981) are some of the most common measures of whether arbitragers have guaranteed market efficiency and kept prices in line with fundamentals.

In the simple efficient markets model, the real price of share at $t$ ime $t, P_{t} .$. should be equal to the value of all expected future dividends discounted at a constant rate. If people follow this pricing rule, the price $P_{t}$ may be considered the fundamentals, perfect foresight or ex post rational price of the stock. The observed real price of the stock in the market is $P_{t}$. If the market is efficient, then $P_{t}$ should be an optimal forecast of $P_{t}{ }^{*}$, 
that is: $P_{t}=E_{t}\left(P_{t}^{*}\right)$, where $E_{t}$ is the expectation at time $t$. The forecast error will be $u_{t}=P_{t}{ }^{*}-P_{t}$. If this is indeed an optimal forecast, then $P_{t}$ and $u_{t}$ must be uncorrelated. The variance of the sum of two uncorrelated variables is the sum of the variances so that $\operatorname{var}\left(P^{*}\right)=\operatorname{var}(P)+\operatorname{var}(u)$. Therefore, $\operatorname{var}\left(P^{*}\right)>\operatorname{var}(P)$ where the errors are non-zero or the variance of the observed price should be less than the variance of the fundamentals price.

Examining annual indices of American stock prices and dividends over the past century, shiller discovered was that stock price volatility was five to thirteen times too high to be attributed to new information about future dividends. This result was in gross violation of the efficient markets hypothesis, and he attributed it to crowd psychology. Shiller's remarkable finding was subjected to intense criticism and scrutiny by Flavin (1983), Kleidon (1986), Marsh and Merton (1986) and others for problems with the stationarity assumptions and small sample properties of the estimators. The central problem that emerged in subsequent empirical work was that shiller-style tests were really joint tests of a null hypothesis of either market efficiency and a constant real rate of return with a variable equity premium or market efficiency and a constant equity premium and a variable rate of return. The most recent work on the subject by Mankiw, Romer and shapixo (1991) has found very mixed evidence and less striking violations of these joint hypotheses.

Curious to determine whether shiller's findings could be replicated elsewhere, researchers have looked at other stock 
markets. Investigating the British market, Bulkey and Tonks (1989), did not find any serious violations, although they concluded that there were still arbitrage opportunities available. Looking at a longer annual series the British market, De Long and Grossman (1992) attributed the variance bounds violations to shifts in the equity premia, suggesting a strong aversion of investors towards stocks before the First world war. The German stock market lacks continuous series on stock prices and dividends. But examining separate periods, De Long and Becht (1992) found that while the post-World war II market appeared to excessively volatile, the pre-World war I market was not. They conjectured that the dominant role of the big German banks may have made the market less volatile.

The evidence thus compiled does not offer any strong suggestion that bubbles, manias or fads may play any role. However, the testing is largely divorced from the historical literature on these phenomena which claims that they were very short-lived. The data which all these studies employ are indices of annual stock prices and dividends, sometimes spliced together from various sources. The use of this type of annual data implies that if stock prices are not excessively volatile, then the market efficiency hypothesis cannot be rejected for very long periods of time. But, annual data fails significantly to capture what historians have described as departures from market efficiency, such as the relatively brief bull markets of 1929 and 1987, which had durations under two years. Higher frequency price and dividend 
data examined by Rappoport and White (1993) suggest that market prices in 1929 could not be validated by the expected flow of future dividends or other factors.

Historical accounts suggest that there should be more information in individual stocks about the effects of "crowd psychology." Yet, while the use of stock indices may be imperfect, they are proxies for individual stocks. Shiller (1989) showed that an observation that indices are excessively volatile is equivalent to an observation that individual stock prices covary too much on average to accord with the efficient markets hypothesis. Shiller did not himself look at individual stock prices. Instead he examined the comovements in real stock price indices between the U.K. and the U.S. and he found that they appear to be too large to be accounted for in terms of the comovements of real dividends between countries.

The only studies to examine the behavior of high frequency individual asset prices are two papers by Pindyck and Rotemberg (1990, 1992) who look at commodities prices and stock prices. Considering $P_{t}$ to be a vector of stock returns, they seek to determine whether once fundamentals are accounted for there is any significant comovement between observed individual stock returns, that is, they examine the off-diagonal elements of the var(u) matrix.

Pindyck and Rotemberg (1992) show that there are two possible sources of comovement of the returns of correctly priced stocks: changes in the discount rate for the immediate holding period 
(which is the same for all firms), and correlated revisions of the expected present discounted value of the future earnings streams. changes in the discount rate should be reflected by macroeconomic variables that affect the overall level of returns in the economy. Revisions in expectations may be correlated between firms in related activities. Thus, there is evidence of excessive comovement of returns if, after controlling for these macroeconomic and industry effects, returns are still correlated across firms.

In their study covering 1969 to 1987, Pindyck and Rotemberg formed groups of companies in unrelated lines of business. As a check on this independence, they showed that earnings of the firms in each group were uncorrelated over time. This fact supports the presumption that any within-group correlation of returns must be due to common responses to underlying macroeconomic factors. They then regressed the time series of returns for each firm on macroeconomic variables designed to capture temporal variation in discount rates that result from economy-wide developments. These variables included current and lagged values of the growth of industrial production and prices, the 3-month T-bill rate, the lagged dividend price ratio for the market as a whole, and the contemporaneous rate of return on the market. The residuals from these regressions should be uncorrelated for firms within each group, if stocks are correctly priced, because sources of comovement have been removed. Pindyck and Rotemberg show that the likelihood ratio test statistic for the null of a diagonal covariance matrix (no excess comovement of the stock returns in a 
group) is $\mid R_{\mid}(T / 2)$, where $\hat{R}$ is the estimated correlation matrix of returns, and $T$ is the number of time series observations. Minus twice the $\log$ of this statistic has a chi-square distribution with $m(m-1) / 2$ degrees of freedom, where $m$ is the number of firms in the group. In a further test they include latent variables to capture unobserved market expectations. For all models the null hypothesis of no excess comovement was clearly rejected.

The appearance of additional comovement between stock returns suggests the possibility that there is some contagion or infection between stocks. If investors were only following fundamentals then the movement of one stock should not be related to another once all fundamentals have been accounted for. If they do move together then investors may be behaving as noise traders using the "irrelevant" information from other stock prices to price a stock. A rise in the value of a few stocks may lead these investors to reevaluate other stocks simply because they believe this is an indication that the rest of the market should rise. However, Pindyck and Rotemberg do not believe that this is the case and offer some additional evidence the observed comovement is the product of company size and degree of institutional ownership, suggesting market segmentation.

\section{Testing for Crowd Behavior in the 1920 s and 1930 s}

To examine the behavior of individual stocks, we have assembled a new body of data, consisting of the individual end-of- 
month prices of 29 of the 30 stocks that composed the Dow Jones Index in 1929 and their dividends from 1920 to 1934. Before 1926, the Wall street Journal and the Commercial and Financial Chronicle supplied stock prices. For the period 1926-1934, the CRSP tapes provided the price data. Dividends for the whole period were found in Moody's Manual of Investments. Individual stock prices and dividends were adjusted to correct for stock splits and stock dividends as recorded in Moody's.

This sample of stocks includes some stocks that were prominent in contemporary accounts but also some that were quiescent. The stocks in the Dow Jones Index for 1929 were selected because most had been on the New York Stock Exchange for long enough to provide a decent time series. ${ }^{1}$ However, not all of them had been in existence or been listed on the New York stock Exchange as far back as 1920.2

Figure 1 shows the mean, standard deviation, skewness, and kurtosis for this cross-section of stock returns over the whole period. Perhaps, the most striking feature of these four plots is

${ }^{1}$ The index at this date had thirty stocks; up until september 29 , 1928, there had been only twenty. The stocks in the index changed little from September 1928 to July 18, 1930, when there was a turnover of seven companies. In 1929, there were only two changes, National Cash Register was substituted for Victor Talking Machine in January and Curtiss-Wright for Wright Aeronautical in september. (Stillman, 1986, p. 56). Only 29 stocks were used in this sample. Recent creations--National Cash Register and CurtissWright--were not employed and data for Victor Talking Machine was not found.

${ }^{2}$ It is worthwhile to note that in the early 1920s, trading among even prominent stocks could be quite limited. During the months of July and August quotations were difficult to find before 1929 . 
that one must look quite carefully to locate the boom beginning in March 1928 and the crash of october 1929. For ready identification, these dates are marked by vertical dashed lines. Note that the most dramatic movements occurred during the turbulence of the early 1930s. It is difficult to establish a reasonable benchmark against which the experience of 1928-1929 can be compared. One candidate is the "coolidge market" (Galbraith, pp. 14-15) during which prices rose almost steadily from mid-1924 to the end of 1925, which is similarly marked by vertical dashed lines. In contrast to the boom of 1928-1929, the upward movement during the Coolidge market is quite homogeneous across stock returns. ${ }^{3}$ The standard deviations in $1928-1929$ are higher, and stock returns are more skewed and show more bunching in the tails. If these two eplsodes were both based on a general improvement in business conditions, then there should be no marked difference between them. While a growing economy certainly underlay the general rise in stocks in 1928 and 1929, their performance was extraordinarily uneven. The second, third and fourth moments of the stock returns suggest considerable divergence among the experiences of individual stocks. Barrie wigmore (1985, p. 86) noted this phenomenon in his detailed analysis of the performance of a broad range of stocks. He concluded that "exaggerated valuations" were "for individual companies rather than whole industries." Thus, excess comovement of the market is not easily

\footnotetext{
smaller.

${ }^{3}$ The number of stocks during the coolidge market was slightly
} 
ascertained from the behavior of stock returns alone.

We adopt the framework developed by Pindyck and Rotemberg to test for comovement, subject to the limitations of our data. These limitations affect the way we control for shared industry effects. The small size of the sample of firms we have prevents the selection of a sufficiently large number of nonoverlapping groups of firms. Furthermore, we do not have earnings data on the firms, to provide a check on independence. Consequently, we calculate the comovement test statistics for a large number of groups of six firms selected from our 29, using a random sampling procedure. For brevity and clarity, we shall refer to these randomly selected groups of six firms as subsets. Each subset of firms contains no more than one firm from the each of the eight industrial categories detailed in Table 1, with the probability of a particular industrial category appearing in a subset is equal to that category's preponderance in the population of 29 firms. Thus, for example, there is a chance of $2 / 29$ that any subset will include a firm in the retailing category, while there is a 5/29 chance that it will contain an automobile industry firm. Then, given a subset that contains a retailing firm, there will be an equal chance that the firm is Sears or Woolworths, and so forth.

This sampling procedure ensures that none of the industrial categories will be over- or under-represented relative to its presence in the group of 29 firms, while the use of results from a large number of randomly sampled subsets guards against arbitrariness in developing the subsets. It raises the further 
problem of the appropriate critical value for the test. The 1 percent critical value for the null of no comovement among a single subset of six firms ( 15 degrees of freedom) is 30.6 ; however, our random sampling procedure generates a large number of such test statistics from subsets of firms whose membership differs but nevertheless overlaps with high probability. We are thus faced with assessing the significance of a list of chi-square statistics among which there is a complicated pattern of statistical dependence. Accordingly, we develop critical values by Monte Carlo simulation. Each run of the simulation is based on 29 T-vectors of independent standard normal variates, each representing an firm. These 29 vectors are partitioned into industry groups with numbers of members corresponding to those in Table 1 . One hundred subsets of six firms are then selected, according to the protocol described above, and the comovement statistics calculated for each subset. Each run mimics the dependence due to overlapping firms among the subsets, while ensuring that the data on which the correlation statistics are based are genuinely independent. For each run, we tabulated the number of the one hundred comovement statistics that exceed the 1 percent (upper) critical values for a single chisquare statistic with 15 degrees of freedom $(m=6)$. We then carried out 1000 such runs, producing a distribution, under the null hypothesis, of the number of rejections (individual comovement statistics in excess of 30.6) among 100 subsets of the same underlying returns data. The upper 5 percent and 1 percent critical values of this distribution are shown in Table 2 . 
Our tests for comovement among the returns of firms are based on residuals obtained from time series regressions for each firm's returns on variants of the list of regressors used by $P$ indyck and Rotemberg. We experimented with current and/or one lag of the growth rates of aggregate industrial production (DIP), wholesale and consumer prices (DWP and DCP), the contemporaneous rate of interest on 90-day bankers' acceptances (BA), the seasonallyadjusted, lagged (equal-weighted) dividend-price ratio for the stocks in the sample (DVP $(-1)$ ), and the contemporaneous (equal weighted) return on the stocks in the sample, which we call the "market return" (MR). The results of these regressions are not shown; curiously, very few of the macroeconomic variables display any significance, a result similar to Pindyck and Rotemberg's finding for their sample. In contrast to their results, we find that the lagged dividend-price ratio for the market is of little use in predicting individual returns. The only variable that has marked explanatory power is $\mathrm{MR}$.

Table 2 exhibits the results for comovement tests on firms' residuals derived from four sets of regressors. Sets (a) and (b) are similar to those used by Pindyck and Rotemberg; set (c) drops the lagged macro variables in (a), and (d) employs only the market return. Each comovement test is run on residuals from monthly regressions over three different samples: 1920.02-26.12, 1927.0130.12, and 1931.01-1934.12. Within each sample, the results are uniform across models (a)-(d). After attempting to control for potential economy-wide and industry-specific sources of comovement 
among stock returns we still find very strong evidence for comovement. The null of no comovement is rejected at the 1 percent level in every case. However, there is least evidence of comovement when only the market return is used in the preliminary regressions ${ }^{4}$. In general, these results are similar to those found by Pindyck and Rotemberg. 5

By looking at the comovement of stock prices across three periods we found a surprising pattern, which allows us to draw a different interpretation from the one suggested by pindyck and Rotemberg. Their finding of substantial excess comovement is open to a common criticism of all studies that do not accept the market efficiency hypothesis that they have not adequately accounted for fundamentals. Hamilton (1986) and Hamilton and whiteman (1985) have shown that if there is some fundamental unobserved by the econometrician but known to the market participants, then asset prices will not appear to be driven by fundamentals. The problem is that what researchers are conducting is a joint test specification test for fundamentals and market efficiency. Consequently, Pindyck and Rotemberg look for an explanation elsewhere and find that some of the excess comovement can be partly explained by company size and degree of institution ownership,

4 Notice that there is no presumption that the evidence for comovement will necessarily be lessened by including more (potentially spurious) variables in the preliminary regressions. while this lowers the variance of the return residuals for an individual firm, it may lower the covariance of return residuals across firms by a greater or lesser amount.

${ }^{5}$ We did not include latent variables in any of the regressions in this version of the paper. 
suggesting market segmentation.

Pindyck and Rotemberg's explanation is a plausible one for their broad selection of stocks. However, it is difficult to imagine that for stocks in the Dow Jones Industrial average that any shift in market segmentation could have occurred over the three periods we examine. The noise trading approach seems to offer a more plausible explanation for our results. Because of the uniformity of results across models of individual firm returns, it is useful in comparing the results across time periods, to focus only on row (d). First, there is a distinct rise in comovement between stock returns from the pre-boom period to the boom. There is excess comovement for 1920 to 1926 but it rises to 1927 to 1930 . This fact accords with the historical suggestions of the entrance of a new generation of unschooled investors responding to hot tips, rumors and general euphoria. What is surprising is that comovement seems even stronger in the third period, 1931-1934. On the face of it, the bubble may have burst and the naive or seminaive investors had dropped out of the market. However, we do know that by any measure this was the period of the greatest volatility in over two hundred years of the American stock market (wilson, Sylla, and Jones, 1991). This volatility was drive by constant domestic and foreign economic policy surprises. ${ }^{6}$ Investors were clearly shaken by the events of the 1930s, and they may very well have been so nervous that they reacted even more to the change in

\footnotetext{
${ }^{6}$ Employing an options-pricing approach to the brokers' loan market, Rappoport and White $(1994)$ found that actual or realized volatility was much higher than expected or implied volatility.
} 
the prices of other stocks than to the specific stock fundamentals or economy-wide fundamentals. The "crowd" was now nervous and apprehensive.

\section{Conclusion}

Whether the efficient markets hypothesis accurately describes the behavior of the stock market in the 1920 s will continue to be a subject of heated debate for the future given the imperfect methodology for testing and the strongly held beliefs of researchers. However, the exercise conducted in this paper suggests that stock returns paralleled one another too closely to be explained by any common industry or economy-wide factors that we could measure. Our results are thus consistent with the possibility that a fad or crowd psychology played a role in the rise of the market, its crash and subsequent volatility. Yet, the possibility remains that, in spite of our use of a broad range of macroeconomic variables, we have not succeeded in extracting all the common factors that drove stock prices. Our statistical analysis of comovement is subject to problems of errors-invariables, arising from the fact that we have used realized values of returns and other variables to test theories that in fact deal with anticipations. 
Allen, Frederick Lewis, Only Yesterday, An Informal History of the Nineteen-Twenties (New York, 1931).

Board of Governors of the Federal Reserve system, Banking and Monetary Statistics (Washington, D.C., 1943).

Bulkey, George and Ian Tonks, "Are UK Stock Prices Excessively Volatile?: Trading Rules and Variance Bounds Tests," Economic Journal (December 1989), pp. 1083-98.

Commercial and Financial Chronicle (New York, 1928 and 1929).

De Long, J. Bradford and Marco Becht, "'Excess Volatility' and the German Stock Market, 1876-1990," (mimeo, March 1992).

De Long, J. Bradford and Richard S. Grossman, "Excess Volatility and the London Stock Market, 1870-1990," (mimeo, November 1992).

De Long, J. Bradford, Andrei Shleifer, Lawrence H. Summers, Robert J. Waldman, "Noise Trader Risk in Financial Markets," Iournal of Political Economy, 98 (Aug. 1990), pp. 703-38.

De Long, J. Bradford, and Andrei Shleifer, "The Bubble of 1929: Evidence from Closed-End Funds", Journal of Economic History, 51 (Sept. 1991), pp. 675-700.

Fisher, Lawrence, "Some New Stock-Market Indexes," Journal of Business (1966).

Flavin, Marjorie A., "Excess volatility in the financial markets: A reassessment of the empirical evidence," Journal of Political Economy (1983), 929-56.

Galbraith, John Kenneth, The Great Crash 1929 (Boston, 1954).

Hamilton, James D., "On Testing for Self-fulfilling Speculative Price Bubbles", International Economic Review 27, (October 1986), pp. 545-52.

Hamilton, James D., and Charles H. Whiteman, "The Observable Implications of Self-Fulfilling Expectations," Journal of Monetary Economics 16 (Nov. 1985), pp.353-73.

Kleidon, Allan W., "Variance bounds tests and stock price valuation models," Journal of Political Economy (October 1986), 953-1001.

Ladies Home Journal, "Ëverybody Ought to Be Rich," (August 1929). 
Le Roy, Stephen F. and Richard D. Porter, "The prevent-value relation: Tests based on implied variance bounds," Econometrica (1981), pp. 555-74.

Mankiw, N. Gregory, David Romer and Matthew D. Shapiro, "Stock Market Forecastability and Volatility," A Statistical Appraisal," (1991), pp. 455-77.

Marsh, Terry A. and Robert C. Merton, "Dividend variability and variance bounds tests for the rationality of stock market prices," American Economic Review (June 1986), 483-98.

Moody's Manual of Investments, Industrial securities (New York, various years).

Pierce, Phyllis, ed., The Dow Jones Averages, 1885-1985 (Homewood, IL, 1986$)$.

Pindyck, Robert S. and Julio J. Rotemberg, "The Excess Co-Movement of Commodity Prices," Economic Journal (December 1990).

Pindyck, Robert S., and Julio J. Rotemberg, "The Comovement of Stock Prices" (mimeo, 1992).

Rappoport, Peter, and Eugene N. White, "Was There a Bubble in the 1929 Stock Market?" Journal of Economic History (September 1993), $549-74$.

Rappoport, Peter, and Eugene N. White, "Was the Crash of 1929 Expected?" American Economic Review (forthcoming 1994).

Shiller, Robert J., "Do Stock Prices Move Too Much to be Justified by Subsequent Changes in Dividends," American Economic Review (June 1981 ).

Shiller, Robert J., "Comovements in Stock Prices and Comovements in Dividends," Journal of Finance (July 1989), pp. 719-29.

standard \& Poor's Trade and securities statistics (Standard \& Poor's Corporation, 1964).

Stillman, Richard, Dow Jones Industrial Average: History and Role in an Investment Strategy (Homewood, IL, 1986).

White, Eugene N., "Banking Innovation in the 1920s: The Growth of National Banks' Financial Services," Business and Economic History (1984).

wigmore, Barrie A., The Crash and its Aftermath (westport: Greenwood Press, 1985).

wilson, Jack w., Richard E. Sylla, and Charles P. Jones, "Financial 
Market Panics and Volatility in the Long Run, 1830-1988," in Eugene $N$. White, Crashes and Panics: The Lessons of History (Homewood, IL, 1990). 


\section{Table 1 \\ Industrial Groups}

Chemicals: Allied Chemical, Texas Gulf and Sulphur, Union Carbide Automotive: Chrysler, General Motors, Goodrich, Mack Truck, Nash Primary Metals: American Smelting and Refining, Bethlehem Steel, International Nickel, U.S. Steel, American Can

Food: American Sugar, American Tobacco, General Foods

oil: Atlantic Refining, Texas Corporation, standard oil of New Jersey, North American Company

Retailing: Sears Roebuck, Woolworth

Machinery and Equipment: Westinghouse, International Harvester, General Railway Signal

New Industries: Paramount, RCA, and wright Aeronautical 
Tosts for comorement of Individual Firms' stock prices

Number of subsets of $s i x$ flrms yielding

comovement statistlcs in excess of $30.6^{2}$

(Maximura possible $=100$ )

Regressors in Model of

Individual Firm Returns ${ }^{2}$

(a; DIP, DIP $(-1), \operatorname{DWP}, \operatorname{DWP}(-1)$, $D C P, D C P(-1), D V P(-1), B A$

$\begin{array}{ccc}1920-26 & \frac{1927-30}{1931-34} \\ 91 & 100 & 100 \\ 13 & 21 & 52 \\ 91 & 100 & 100 \\ 10 & 18 & 45\end{array}$

(i) As (a), plus MR

45

Critical values ${ }^{3}$

$5 z$

17

6

3

$\begin{array}{ll}6 & 6 \\ 8 & 8\end{array}$

1 The tests for comovement examine whether returns of groups of six flrms in different industries are mutualiy correlated, after correcting for shared macroeconomic influences on returns. The number 30.6 is the 1 signiflcance level for the ilkellhood ratio cust of the null that the covarlance ratrix of (residual) returns is a diagonal matrix. For each model of individual firm returns, one huidred different permutations ("gubsets") of six Individual firms in different industrles were randonly selected from the 29 rirms on whlch data were avallable. The entrles in the table roport the number of these 100 subsets that produce refection of the diagonal covariance matrix null. An entry in excess of $6(8)$ is clgniflcant at the 5i(1t) level. see text, pp.8-10, for complete deta11s.

All data are monthly. DVP is the seasonally aujustedaggregate dlvidend-price ratio, BA is the rate on 90-day vankers' acceptances, and MR the average return on the 29 Dow Jones securities. DIP, DWP, and DCP are, respectively, the monthly rates of change in lndustrlal production, wholesale prices and consurer prices.

3 Based on 1000 simulations using 50 and 100 time series observations representing individual firm returns. See text, p.10 for full details. 


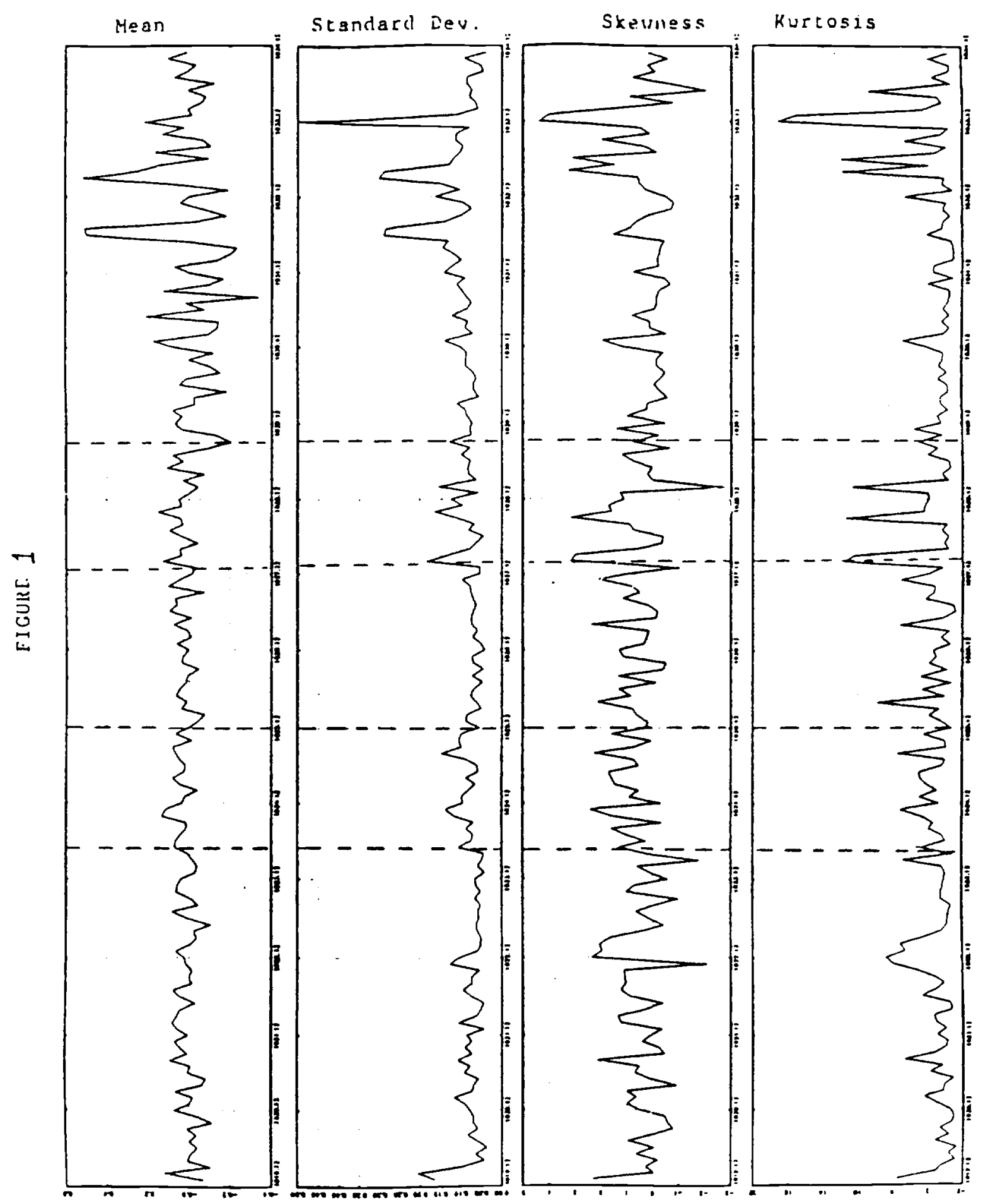

